\title{
Ficus palmata FORSKÅL (BELES ADGI) as a source of milk clotting agent: a preliminary research
}

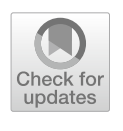

Desta Berhe Sbhatu ${ }^{1 *} \mathbb{D}$, Hailekiros Tadesse Tekle ${ }^{1}$ and Kiros Haddish Tesfamariam²

\begin{abstract}
Objective: The demand for cheese, the insufficient supply and high cost of rennet, and the ethical issues of harvesting rennet oblige us to search for suitable alternatives of finding new proteases from plants. Ficus palmata ForSKÅL (Moraceae) is one of the plants producing a protease called ficin that coagulates fresh milk. This study aims to study the milk coagulating abilities of bark, leaf, and stem powders of F. palmata ForsKÅL.

Results: Stem powder has yielded better results. Chemical analyses of the powders have revealed that the percentage of crude protein of leaf, bark, and stem powders were 4.17,7.39, and 16.26. This is an indication of the suitability of stem biomass as source of the enzyme of interest. Further research needs to aim at qualitative and quantitative analyses of milk-coagulating enzymes of F. palmata ForSKÅL stem biomass to get new insights into industrial extraction of the enzymes of interest.
\end{abstract}

Keywords: Coagulation, Ficin, Ficus palmata ForskÅL, Milk, Powder

\section{Introduction}

Cheese is an important dairy product of high economic and nutritional significance. Cheese preserves essential nutrients in milk and is an excellent source of proteins, fats, minerals, and vitamins. Cheese making is carried out using animal rennin-called rennet. Rennet helps in coagulating the casein of milk. It is characterized by low proteolytic and high milk clotting activity [1]. The milk clotting property of an enzyme is important with regard to the quality and yield of the cheese [2,3]. The growing demand for cheese, the insufficient supply and high cost of rennet, and the associated ethical issues of harvesting rennet oblige us to search for a suitable alternative. There is a growing research interest in recent years towards finding new proteases with milk coagulation potential from plants [4-6]. This study aims to conduct a preliminary research on milk coagulating capacity of

*Correspondence: desta.sbhatu@mu.edu.et

${ }^{1}$ Department of Biological and Chemical Engineering, Mekelle Institute

of Technology, Mekelle University, PO Box 1632, Mekelle, Ethiopia

Full list of author information is available at the end of the article bark, leaf and stem powders of Ficus palmata ForSKÅL (Moraceae).

Ficus palmata belongs to genus Ficus that includes about 750 tree and shrub species, with several medicinal plants, primarily occurring in subtropical and tropical regions of the world. Ficus is remarkable for the large variation in the habits of its species [7]. Ficus species are among the first plants to be cultivated by humans [8]. The plants are usually monoecious with small flowers without petals and nectarines [9]. The fruits of Ficus species vary from yellowish-green to coppery, bronze, or dark-purple. They are known for their nutritive value, consumed as fresh or dry and for their mild laxative activity and high alkalinity [10]. They are propagated through cutting of mature woods or grafts [11].

\section{Main text \\ Materials and methods \\ Identification and collection of plant materials}

F. palmata ForSKÅL is the most common fig in Ethiopia. It is shrub to small tree growing between 1700 and 2400 masl in water courses or river banks. It releases white latex up on removing its unripe fruits, breaking its leaf 
petioles, cutting its shoot tips, and slashing its stem [12]. Whereas the fruits are eaten, the latex is used in treating skin warts $[12,13]$. Bark, leaf and stem biomass was collected by the researchers from wild stands in Abala and Hiwane, Northeastern Ethiopia following ethical and legal procedures. Collected specimens include barks (green and fibrous), leaves (green to deep green), and stem (woody). The specimen is identified by Professor Mirutse Giday. Specimens of the plant are deposited in the Aklilu Lemma Institute of Pathobiology, Addis Ababa University (Voucher No. of AS-16-2017).

\section{Preparation of F. palmata leaf, bark and stem powders}

The bark and leaf biomass of the plant was dried in a ventilated oven at $45{ }^{\circ} \mathrm{C}$ for $24 \mathrm{~h}$; and immediately milled finely into powder using grinding machine. Stem biomass was dried at room temperature for 4 days and ground into powder. The powdered biomasses of bark and leaf were treated with methanol to extract the chlorophyll. Chlorophyll extraction was carried out by treating $100 \mathrm{~g}$ of the biomass with $80 \mathrm{~mL}$ methanol (purity grade 98\%) in Erlenmeyer flasks. Flasks holding the mixture were stirred every $30 \mathrm{~min}$ to enhance the extraction. Then, the flasks were placed in a Sonicator Bath (Branson 8210) and sonicated at $40{ }^{\circ} \mathrm{C}$ for 30 min for further stirring and mixing. The mixture in each flask was filtered using filter paper; and the flasks were washed with $30 \mathrm{~mL}$ and then with $50 \mathrm{~mL}$ ethanol. Filtrates were poured into roundbottom flasks and the solvents were concentrated in vacuo at about $11 \mathrm{~mm} \mathrm{Hg}$ up to $5-10 \mathrm{~mL}$ using rotavapor with the help of water bath at $40^{\circ} \mathrm{C}$. Finally, the biomass was put in $30 \mathrm{~mL}$ vessels to evaporate the solvent and left open overnight in a well-ventilated hood to further evaporate traces of the solvent. About $150 \mathrm{~g}$ of biomass was collected for each plant part. On the other hand, powdered biomass of stem was mixed with distilled water $(250 \mathrm{~g} / \mathrm{L}, \mathrm{v} / \mathrm{w})$ in Erlenmeyer flask, and was shaken for 15-20 min. Each mixture was filtered using Whatman No. 1 filter paper. The biomass was, then, collected and centrifuged at $4000 \times$ for $10 \mathrm{~min}$ to reduce the fibers. Finally, the precipitates were loosened, put into distilled water, and filtered with the same filter paper. These procedures helped us harvest $150 \mathrm{~g}$ of powdered biomass.

\section{Milk coagulation using crude biomass powders}

The coagulation abilities of bark, leaf, and stem powders were tested with $1 / 2,1,1 \frac{1}{2}$, and 2 teaspoons for 50 , $100,150,200,250,300,350,400,450$, and $500 \mathrm{~mL}$ of fresh cow milk. This test was made to identify the minimum effective amount of $F$. palmata that can coagulate $50 \mathrm{~mL}$ of fresh cow milk. Data on coagulating abilities of the powders were expressed in terms of time of coagulation, hence time of coagulation of the treatments were recorded. Up on establishing the minimum effective amount of powder (i.e. $1 / 2$ teaspoons) to coagulate $50 \mathrm{~mL}$ fresh cow milk, the coagulating capacities of bark, leaf, and stem powders were tested with 30 replications each. Data on time for coagulation (in hours) were collected.

\section{Comparison of coagulating capacities of stem, bark, and leaf extracts}

Once it was established that $1 / 2$ teaspoon of powder of bark, leaf, and stem was sufficient to coagulate $50 \mathrm{~mL}$ fresh cow milk, their coagulating capacities-in terms of coagulation time-were compared. Powder extracted from bark, leaf, and stem biomass was mixed with fresh cow milk at the rate of $1 / 2$ teaspoon per $50 \mathrm{~mL}$ of milk. There were 30 treatments for each of the plant powders. Data on coagulation time were collected and organized for analysis.

\section{Gross chemical analyses of bark, leaf, and stem powders}

Bark, leaf, and stem biomass of $F$. palmata was air-dried in shade for $72 \mathrm{~h}$. The dried biomass was grinded grossly with mortar and pestle, and finely with grinding machine to collect enough powder. Samples of powders were then sent for gross chemical analyses in JIJE LABOGLASS Pvt. Ltd. Co., Addis Ababa, Ethiopia. The analyses were made for moisture content (AOAC Official Method 925.10), crude fat (AOAC Official Method 920.39-Soxhlet/Gravimetric), crude protein (ES ISO 1871:2013), crude ash (AOAC Official Method 923.03), carbohydrate (by difference), and crude fiber (AOAC Official Method 962.09-Gravimetric).

\section{Statistical analyses}

Collected data were analyzed and mean values were compared using appropriate inferential statistical methods at a priori established significance level of $p \leq 0.01$.

\section{Results \\ Establishing the optimum amount powder for effective coagulation}

The coagulating capacity of stem powder increases with increasing the amount of powder used. A $1 / 2,1$, and $1 \frac{1}{2}$ teaspoons of stem powder were ineffective in initiating any coagulation of cow milk in 200, 300, and $400 \mathrm{~mL}$, respectively. Similar tests were carried out with bark and leaf powders. In both cases, the coagulating capacities of the powders increase with increasing their amounts and decreases with increasing the volume of milk. Thus, $1 / 2,1$, and $1 \frac{1}{2}$ teaspoons of bark powders were ineffective in coagulating cow milk in 150,250 , and $300 \mathrm{~mL}$, respectively. Likewise, $1 / 2,1$, and $1 \frac{1}{2}$ teaspoons of leaf powder were ineffective in causing the coagulation of cow milk in 150,250 , and $400 \mathrm{~mL}$, 
Table 1 Coagulating capacity of bark, leaf, and stem powders of F. palmata

\begin{tabular}{|c|c|c|c|c|c|c|c|c|c|c|c|c|}
\hline \multirow{3}{*}{$\begin{array}{l}\text { Milk volume } \\
(\mathrm{mL})\end{array}$} & \multicolumn{12}{|c|}{ Coagulating time (in h) of F. palmata powder in teaspoons } \\
\hline & \multicolumn{4}{|c|}{ Bark } & \multicolumn{4}{|l|}{ Leaf } & \multicolumn{4}{|c|}{ Stem } \\
\hline & $1 / 2$ & 1 & $1 \frac{1 / 2}{2}$ & 2 & $1 / 2$ & 1 & $1 \frac{1 / 2}{2}$ & 2 & $1 / 2$ & 1 & $1 \frac{1 / 2}{2}$ & 2 \\
\hline 50 & 0.91 & 0.78 & 0.60 & 0.46 & 1.33 & 1.03 & 0.81 & 0.63 & 0.70 & 0.50 & 0.32 & 0.21 \\
\hline 100 & 1.30 & 1.01 & 0.76 & 0.65 & 1.83 & 1.33 & 1.01 & 0.75 & 1.40 & 1.20 & 0.75 & 0.45 \\
\hline 150 & - & 1.25 & 1.06 & 0.85 & - & 1.58 & 1.26 & 0.95 & 1.70 & 1.42 & 0.91 & 0.50 \\
\hline 200 & - & 1.45 & 1.20 & 1.05 & - & 2.25 & 1.55 & 1.20 & - & 1.58 & 1.30 & 0.91 \\
\hline 250 & - & - & 1.58 & 1.26 & - & - & 1.83 & 1.48 & - & 1.75 & 1.53 & 1.16 \\
\hline 300 & - & - & 2.00 & 1.45 & - & - & 2.36 & 1.65 & - & - & 1.83 & 1.41 \\
\hline 350 & - & - & - & 2.41 & - & - & 2.83 & 2.20 & - & - & 2.11 & 1.63 \\
\hline 400 & - & - & - & 2.96 & - & - & - & 3.25 & - & - & - & 2.17 \\
\hline 450 & - & - & - & 3.33 & - & - & - & 4.13 & - & - & - & 2.58 \\
\hline 500 & - & - & - & 3.80 & - & - & - & 5.01 & - & - & - & 3.01 \\
\hline
\end{tabular}

Table 2 Coagulating capacity of $1 / 2$ teaspoon of bark, leaf, and stem powder for $50 \mathrm{~mL}$ milk

\begin{tabular}{|c|c|c|c|c|c|}
\hline \multirow{2}{*}{ Sources of powder } & \multicolumn{2}{|c|}{ Mean time (SD) in $\min$} & \multicolumn{3}{|c|}{ ANOVA } \\
\hline & Mean 1 & Mean 2 & $d f$ & $F$ & $p$ \\
\hline em vs. leaf & $43.63(1.16)$ & $78.73(1.28)$ & 59 & $12,343.75$ & 0.000 \\
\hline Stem vs. bark & $43.63(1.16)$ & $56.70(1.37)$ & 59 & 1592.66 & 0.000 \\
\hline Bark vs. leaf & $56.70(1.37)$ & $78.73(1.28)$ & 59 & 4131.00 & 0.000 \\
\hline
\end{tabular}

respectively (Table 1 ). In addition to these observations, Table 1 shows that the same amount of powder from bark, leaf, and stem have varied in their coagulating capacity of the same volume of milk.

\section{Coagulating capacities of stem, bark, and leaf extracts}

This experiment showed that the average time required to coagulate $50 \mathrm{~mL}$ of milk with $1 / 2$ teaspoon stem powder $(43.63 \pm 1.16 \mathrm{~min})$ is significantly lower than bark powder $\quad(56.70 \pm 1.37 \mathrm{~min}) \quad(\mathrm{F}=1592.66 ; \mathrm{p} \leq 0.000)$ and leaf powder $(78.73 \pm 1.28 \mathrm{~min})(\mathrm{F}=12,343.75$; $\mathrm{p} \leq 0.000$ ). Likewise, the average time required to coagulate $50 \mathrm{~mL}$ of milk with $1 / 2$ teaspoon of bark powder is significantly lower than with leaf powder $(\mathrm{F}=4134.00$; $\mathrm{p} \leq 0.000$ ) (Table 2).

\section{Gross chemical analyses of bark, leaf, and stem powders}

Findings of the chemical analyses are given in Table 3. Stem powder has more than twice and nearly four times crude protein compared to bark and leaf powders, respectively. This may be the reason for the better coagulating capacity of stem powder.
Table 3 Gross chemical analyses of bark, leaf, and stem powder

\begin{tabular}{llrrr}
\hline S. no & Testing parameters & \multicolumn{3}{c}{ Source of dry powder (\%) } \\
\cline { 3 - 5 } & & Bark & Leaf & Stem \\
\hline 1 & Moisture content & 8.62 & 6.64 & 7.64 \\
2 & Crude ash & 10.58 & 3.11 & 15.74 \\
3 & Crude protein & 7.39 & 4.17 & 16.26 \\
4 & Crude fat & 6.02 & 2.43 & 5.63 \\
5 & Carbohydrate & 67.39 & 83.66 & 54.74 \\
6 & Crude fiber & 24.80 & 50.10 & 12.90 \\
\hline
\end{tabular}

\section{Discussion}

Plant extracts are often used for home-based cheese making and instant on-farm yogurt making in many communities. Many studies reported that many plants are sources of various proteases used in cheese making including papain, bromelin, ficin, oryzasin, and cucumisin. Solanum dubium and other Solanum species [4, 1416], Dead Sea apple (Calotropis procera) [17], Moringa oleifera [18], Balanites aegyptiaca fruit pulp [19], Cynara scolymus L. flower extracts [20-23], Cynara cardunculus L. [24], Albizia julibrissin young seeds [25], sunflower and Albizia seeds [26], melon fruit extracts [27], and Lactuca sativa leaf extracts [28] are sources of cheese making proteases. Ethiopian lowlands and highlands are home to pastoralist and agrarian communities. As the floristic compositions of the many agro-climatic zones of Ethiopia are fairly distinct, the diverse pastoralist and agrarian communities use different plants to coagulate milk at home and on the farm. Typical examples are the use of F. palmata latex for coagulating fresh goat milk in many parts of Northern Ethiopia; the use of fresh leaf of Ocimum lamiifolium Hochst. ex Benth. for coagulating fresh 
cow and goat milk in many parts of Eastern Ethiopia, and use of Solanum fruit juice in coagulating cow and goat milk in Northeastern Ethiopia.

\section{Conclusion}

The study showed that two teaspoons of plant powder can coagulate $500 \mathrm{~mL}$ fresh cow milk in 3 to $5 \mathrm{~h}$ and samples of the stem powder have a high percentage of crude protein. Treatment of barks and leaves with methanol removes chlorophyll leading to the reduction of crude protein content. However, since chlorophyll does not involve in coagulating milk, it can be claimed that the crude protein in the powders is the source of milk-coagulating enzymes. Hence, this study has established that $F$. palmata biomass is an excellent source of milk-coagulating enzymes. Further studies need to aim at qualitative and quantitative biomolecular analyses of milk-coagulating enzymes of the plant.

\section{Limitations}

The test aiming at establishing the optimum amount of powder for effective coagulation was not replicated because it requires large volume of milk.

\section{Abbreviations}

AOAC: Association of Official Analytical Chemists; msal: Meters above sea level; SD: Standard deviation; v/w: Volume by weight.

\section{Acknowledgements}

The authors acknowledge Professor Mirutse Giday for identifying the plant.

\section{Authors' contributions}

All the authors were involved in the planning of the study; HTT and KHT carried out the collection of the plant materials, the experimentation, data collection, and draft manuscript write up, and DBS carried out the data analyses and interpretation as well as manuscript preparation for publication. All authors read and approved the final manuscript.

\section{Funding}

This study was supported by Mekelle University, PO Box, 231, Mekelle, Ethiopia.

\section{Availability of data and materials}

The datasets used and/or analyzed during the current study are available from the corresponding author on reasonable request. Specimens of the plant have been deposited in the Aklilu Lemma Institute of Pathobiology, Addis Ababa University (Voucher No. of AS-16-2017).

\section{Ethics approval and consent to participate}

Not applicable.

\section{Consent for publication}

Not applicable.

\section{Competing interests}

The authors declare that they have no competing interests.

\section{Author details}

${ }^{1}$ Department of Biological and Chemical Engineering, Mekelle Institute of Technology, Mekelle University, PO Box 1632, Mekelle, Ethiopia. ${ }^{2}$ Department of Forensic Medicine, School of Medicine, College of Health Sciences, Mekelle University, PO Box 231, Mekelle, Ethiopia.
Received: 27 August 2020 Accepted: 12 September 2020

Published online: 18 September 2020

\section{References}

1. Sousa MJ, Ardo Y, McSweeney PLH. Advances in the study of proteolysis during cheese ripening. Int Dairy J. 2001;11:327-45.

2. Mahajan RT, Badgujar SB. Biological aspects of proteolytic enzymes: a Review. J Pharm Res. 2010;3(9):2048-68.

3. Wedholm A, Hallén E, Bach Larsen L, Lindmark-Månsson H, Hans Karlsson A, Allmere T. Comparison of milk protein composition in a Swedish and a Danish dairy herd using reversed phase HPLC. Acta Agric Scand Sect A. 2006;56(1):8-15.

4. Ahmed IAM, Morishima I, Babiker EE, Mori N. Characterization of partially purified milk-clotting enzyme from Solanum dubium Fresen seeds. Food Chem. 2009;116(2):395-400.

5. Duarte AR, Duarte DMR, Moreira KA, Cavalcanti MTH, Lima-Filho JLD, Porto ALF. Jacaratia corumbensis O. Kuntze: a new vegetable source for milk-clotting enzymes. Braz Archiv Biol Technol. 2009;52(1):1-9.

6. Upasana CA, Chaturvedi A, Tripathi YB. Assessment of milk clotting activities of plant latex. Asian J Home Sci. 2013;8(2):456-60.

7. Omotosho OE, Oboh G, Iweala EEJ. Comparative effects of local coagulants on the nutritive value, in vitro multienzyme protein digestibility and sensory properties of Wara Cheese. Int J Dairy Sci. 2011;6(1):58-65.

8. Mahami T, Ocloo FCK, Odonkor ST, Owulah C, Coffie SA. Preliminary study on the influence of Moringa seed extracts supplementation on the yield and quality of cottage cheese. Int J Recent Trends Sci Technol. 2012:2(1):4-8

9. Herre EA, Jander CK, Machado CA. Evolutionary ecology of figs and their associates: recent progress and outstanding puzzles. Annu Rev Evol Syst. 2008;39:439-58.

10. Morton J. Figs. In: Morton JF, editor. Fruits of warm climates. Miami: Echo Point Books and Media; 1987. p. 47-50.

11. Wang RW, Sun BF. Seasonal change in the structure of fig-wasp community and its implication for conservation. Symbiosis. 2009;47:77-83.

12. Aweke G. Revision of the genus Ficus L. (Moraceae) in Ethiopia (Primitiae Africanae XI). Meded. Landbouwhogeschool Wageningen. 1979; 79-83.

13. Teklay A, Abrera B, Giday M. An ethnobotanical study of medicinal plants used in Kilte Awulaelo District, Tigray Region of Ethiopia. J Ethnobot Ethnomed. 2013;9:65

14. Guiama VD, Libouga DG, Ngah E, Mbofung CM. Milk-clotting activity of berries extracts from nine Solanum plants. Afr J Biotechnol. 2010;9(25):3911-8.

15. Tsuchida O, Yamagata Y, Ishizuka J, Arai J, Yamada J, Ta-keuchi M, Ichishima E. An alkaline proteinase of an alkalophilic Bacillus sp. Curr Microbiol. 1986;14:7-12.

16. Yousif BH, McMahon DJ, Shammet KM. Milk-clotting enzyme from Solanum dubium plant. Int Dairy J. 1996;6:637-44.

17. Adetunji VO, Salawu OT. West African soft cheese 'wara' processed with Calotropis procera and Carica papaya: a comparative assessment of nutritional values. Afr J Biotechnol. 2008;7:3360-2.

18. Bradford MM. A rapid and sensitive method for the quantitation of microgram quantities of protein utilizing the principle of protein-dye binding. Anal Biochem. 1976:72:248-54.

19. Beka RG, Krier F, Botquin M, et al. Characterisation of a milk-clotting extract from Balanites aegyptiaca fruit pulp. Int Dairy J. 2014;34:25-31.

20. Chazarra S, Sidrach L, Lopez-Molina D, Rodrıguez-Lopez JN. Characterization of the milk-clotting properties of extracts from artichoke (Cynara scolymus L.) flowers. Int Dairy J. 2007;17:1393-400.

21. Llorente BE, Brutti CB, Caffini N. Purification and characterization of a milk-clotting aspartic proteinase from Globe artichoke (Cynara scolymus L.). J Agric Food Chem. 2004;52:8182-9.

22. Roseiro LB, Barbosa M, Ames JM, Wilbey A. Cheesemaking with vegetable coagulants e the use of Cynara $L$. for the production of ovine milk cheese. Int J Dairy Technol. 2003;56:76-85.

23. Sidrach L, Garcia-Canovas F, Tudela J, Rodriguez-Lopez JN. Purification of cynarase from artichoke (Cynara scolymus L.): enzymatic properties of cynarase A. Phytochemistry. 2005;66:41-9. 
24. Macedo IQ, Faro CJ, Pires EM. Specificity and kinetics of the milk-clotting enzyme from cardoon (Cynara cardunculus L.) toward bovine k-casein. J Agric Food Chem. 1993:41:1537-40.

25. Otani H, Matsumori M, Hosono A. Purification and some properties of a milk clotting protease from the young seeds of Albizia julibrissin. Anim Sci Technol. 1991;62:424-32.

26. Egito AS, Girardet J-M, Laguna LE, Poirson C, Mollé D, Miclo L, et al. Milkclotting activity of enzyme extracts from sunflower and Albizia seeds and specific hydrolysis of bovine k-casein. Int Dairy J. 2007;17:816-25.

27. Uchikoba T, Kaneda M. Milk-clotting activity of cucumisin, a plant serine protease from melon fruit. Appl Biochem Biotechnol. 1996;56:325-30.
28. Lo Piero AR, Puglisi I, Petrone G. Characterization of "Lettucine", a serinelike protease from Lactuca sativa leaves, as a novel enzyme for milk clotting. J Agric Food Chem. 2002;50:2439-43.

\section{Publisher's Note}

Springer Nature remains neutral with regard to jurisdictional claims in published maps and institutional affiliations.
Ready to submit your research? Choose BMC and benefit from:

- fast, convenient online submission

- thorough peer review by experienced researchers in your field

- rapid publication on acceptance

- support for research data, including large and complex data types

- gold Open Access which fosters wider collaboration and increased citations

- maximum visibility for your research: over $100 \mathrm{M}$ website views per year

At BMC, research is always in progress.

Learn more biomedcentral.com/submissions 